\title{
ESTABLISHMENT, SPACING DENSITY AND GRAZING EFFECT
}

\author{
M.D. Hare
}

For the production of acceptable yields of grass seeds, attention must be paid throughout the life of the plant towards encouraging the type of growth and development that is likely to result in the maximum seed production from any particular stand during its lifetime.

The lifetime of certified grass seed cropsin New Zealand ranges from one harvest season for Tama ryegrass, to four harvest seasons for perennial ryegrass, six for tall fescue, seven for phalaris and eight for cocksfoot. Management of these stands, particularly the long term stands, is a year round process right from the day harvest is finished until the next season's harvest.

In this paper severalcultural aspects of grass seed production which will encourage consistent high seed yields throughout the lifetime of the stand, and methods of avoiding the decline in seed yields that often comes with stand age, will be discussed. Particular emphasis will be placed on plant density in establishing the stand, time of establishment and post-harvest management.

\section{ESTABLISHMENT}

Site selection: A British bulletin on grass seed production states that the requirements for good quality herbage seed and high seed yields are moderate and well-distributed rainfall during the vegetative growth period in spring and early summer, a fine spell of weather at the time of pollination followed by gentle rain during the filling of the seed, and a dry sunny period for ripening and harvesting. If weather like this occurred every year, consistently high seed yields would probably be obtained without too much difficulty. We can, however, strive to pick sites for grass seed production carefully so that the full seed potential of any particular species is realised.

Soils: Grass seed production requires soils of moderate fertility and the best yields of most cultivars are obtained on land which retains moisture until late in the growing season. For these reasons deep soils, which permit maximum rooting range of the plants at full maturity, are most favoured. The critical moisture requirement occurs after pollination at seed formation time and for most cultivars this phase coincides with a period of high moisture deficit,

Cocksfoot and tall fescue suffer losses in seed production if grown on light soils or if long dry periods occur during November-December, even though they grow well on light land as pasture plants. These two species also suffer more in low rainfall areas from moisture stress than ryegrass, and are therefore especially suitable for growing in areas of high rainfall. 
Vernalisation: Nearly all of the temperate grasses must undergo a period of low temperatures, or short days, or both, before fertile tiller formation can be initiated, Most of the major grass seed areas in New Zealand, i.e., Hawkes Bay, Manawatu, Canterbury and Southland, have suitable periods of low temperatures and short days.

However, some species may require a far longer period of cold temperatures than may be found in some North Island seed growing regions.

Traditionally, Chewings fescue was grown for seed in Otago and Southland. Difficulty has been experienced in attempts to obtain high seed yields of Cook and Tasman fine fescues in the Manawatu and part of the reason, besides management, may be that insufficient tillers are initiated. No detailed work on the vernalisation requirements for Cook and Tasman has been done, but in the Netherlands fine fescues require 12-15 weeks or 2000-2500 hours with temperatures between $0-10^{\circ} \mathrm{C}$ to get adequate fertile tiller induction. Thus it is likely that Cook and Tasman may give higher yields in Otago and Southland, where more fertile tillers may be initiated, than in the Manawatu.

Frost: It is not always appreciated that frost may damage the young grass inflorescence at emergence time, particularly in susceptible species such as cocksfoot. Temperatures below $-1^{\circ} \mathrm{C}$ can cause anther injury and collapsed embryo sacs in some plants leading to poor seed yields. Severe frosts $\left(-2^{\circ} \mathrm{C}\right.$ or more) during seed development in late November and December can shrivel the seed, especially if it is in a high moisture stage. Frost exposure of $-2^{\circ} \mathrm{C}$ for 3 hours or more two weeks after anthesis has reduced the number of wheat grains per ear and also increased sterile floret numbers. A $-2^{\circ} \mathrm{C}$ frost during the first four days of seed development has been shown to reduce seed set in perennial ryegrass. Areas with known heavy frosts during late November and December are likely to have lower seed yields than frost-free areas, and should not be used to grow susceptible species.

Time of establishment: The stronger the plant being harvested, the better the prospects of a good seed yield. For, most grasses sufficient growth must be made by the autumn or early winter of the year prior to taking the seed crop in order to produce the required tiller density in time for vernalising during the winter months. This will give maximum fertile tiller production in the first harvest year. It is the autumn and early winter tillers which contribute most to seed yield.

Farmers generally believe that grasses are less sensitive to sowing times than cereals. However, for high seed yields this is not the case with 'many of the new cultivars.

Several cultivars can be sown only in the spring, with a seed crop 15 months later. Cocksfoot, fine fescue and, in many areas, tall fescue, are very slow establishing and must be spring sown in order to have sufficient tiller production before going into autumn and winter. Wana cocksfoot and Roa tall fescue can be autumn sown, but it must be early autumn (February) to get a 
good seed yield in the first year of establishment. Yields of over $500 \mathrm{~kg} \mathrm{ha"}$ have been reported for both cultivars from early autumn sowings.

Matua prairie grass and Tama ryegrass can be spring sown for seed harvest the same year. The earlier the spring sowing, the more chance there is of getting a good seed yield (Table 1). Matua sown in early autumn will give higher seed yields than late autumn sowings, (Figure 1) because at low temperatures it germinates and establishes slowly, produces few tillers and then grows slowly. These tillers are never as vigorous and never catch up, in terms of development, with early-formed tillers.

Table 1. Spring sown Matua seed yields in the Manawatu

\begin{tabular}{ccc}
$\begin{array}{c}\text { Seeding } \\
\text { fate } \\
\text { kg ha-' }\end{array}$ & \multicolumn{2}{c}{ Sowing date } \\
20 & 3300 & 15 October \\
40 & 3500 & 1100 \\
60 & 3900 & 1300
\end{tabular}

Method of sowing: For grass seed production drilling is generally far superior to broadcasting in terms of subsequent seed yield. Wana cocksfoot produced significantly higher seed yields from drilled stands than broadcast stands (Figure 2). Matua sown in the spring also produces more seed from drilled stands than broadcast stands, particularly if late spring sown (Table 2).

Table 2. The effect of method of sowing on Matua seed yields..

Area

Time of sowing

Seed yield (kg ha-1)

Manawatu

B roadcast Drill

22 September

$330^{\prime} 0$

3800

15 October

800

2100

Canterbury 
With long life stands (4-8 years) it is particularly important to reduce stand density in order to maintain seed yields. This is easier to achieve with drilled stands than broadcast stands and will be discussed in the section of postharvest management.

Plant density, row spacing and sowing rate: For grass seed production it is always better to have a relatively sparse population of strong vigorous plants than a dense population of weak ones. The ideal seed crop has individual plants evenly spaced so that each plant is able to develop fully and produce its maximum number of fertile tillers. A low seed rate is, therefore, implicit in seed growing. The ideal density would be about one mature plant per $15 \mathrm{~cm}$ of drill row in order to allow- vigorous strong tillers to develop. With normal recommended sowing rates this density is nearly always exceeded (Table 3). High seed rates can result in an excessive number of seedlings trying to establish themselves in the rows and competition results in the production of a large number of weak plants and indifferent seed yields in the first and subsequent harvests. Growers should aim for plant populations of between 300-400 plants per metre for perennial ryegrass and 40-100 plants per metre for prairie grass. Cocksfoot and tall fescue populations of about 200 plants per metre will give good seed yields. However, populations below these numbers are not a problem if the plants are established well before the winter.

Table 3. Relationship between seed spacing and row spacing for four different grasses.

\begin{tabular}{|c|c|c|c|c|}
\hline \multirow[t]{3}{*}{ Grass } & \multirow[t]{3}{*}{ Seeds per $\mathrm{kg}$} & \multicolumn{3}{|c|}{$\begin{array}{c}\text { Seeds per } 30 \mathrm{~cm} \text { row at } 1 \mathrm{~kg} \\
\text { sowing rate }\end{array}$} \\
\hline & & \multicolumn{3}{|c|}{ row spacing $(\mathrm{cm})$} \\
\hline & & 18 & 36 & 60 \\
\hline $\begin{array}{l}\text { Perennial } \\
\text { ryegrass }\end{array}$ & $\begin{array}{l}400,000 \\
500,000\end{array}$ & $2-3$ & $5-7$ & $9-11$ \\
\hline Tall fescue & $\begin{array}{lllllll}3 & 0 & 0 & 0 & 0 & 0 \\
4 & 0 & 0 & 1 & 0 & 0 & 0\end{array}$ & $2-3$ & $4-6$ & 7-9 \\
\hline Coc ksfoot & $\begin{array}{l}700,000 \\
900,000\end{array}$ & $4-6$ & 1 & $16-18$ \\
\hline Timothy & $\begin{array}{l}2,400,000 \\
3,000,000\end{array}$ & $16-20$ & $32-40$ & $55-69$ \\
\hline
\end{tabular}

There appears to be a plant density above which high plant numbers fail to compensate for low yields per plant, and below which high yields per plant fail to compensate for low plant numbers. Matua prairie grass sown at $5 \mathrm{~kg}$ ha-' in early autumn produced slightly more seed than stands sown at $20 \mathrm{~kg} \mathrm{ha}^{-1}$ 
Fig. 1

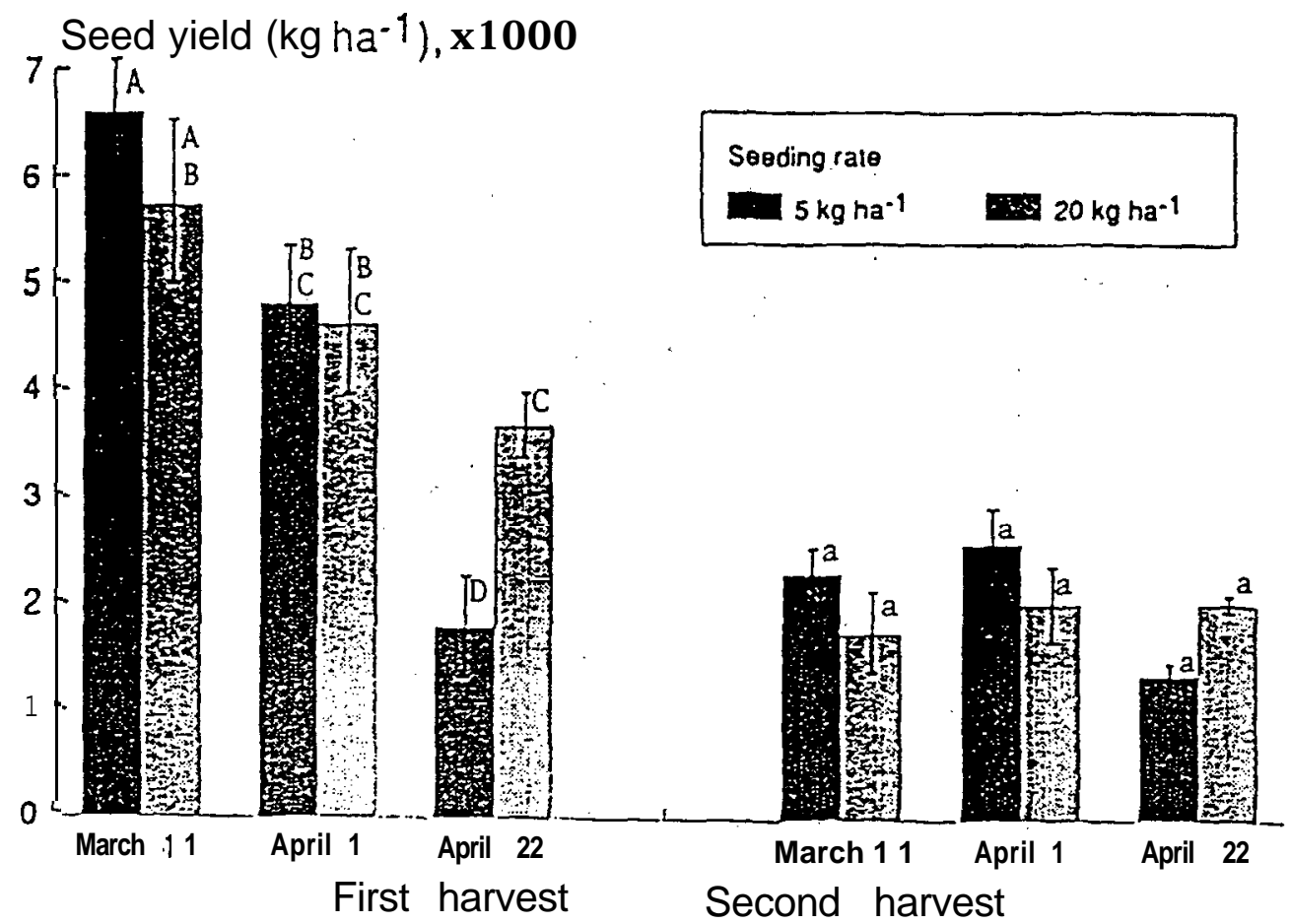

Mean seed yields from matua prairie grass sown at two seeding rates on different dates in autumn 1986. Standard errors of means are indicated and means accompanied by the same letter are not significantly different as indicated by pairwise $t$ 'tests'.

Fig. 2

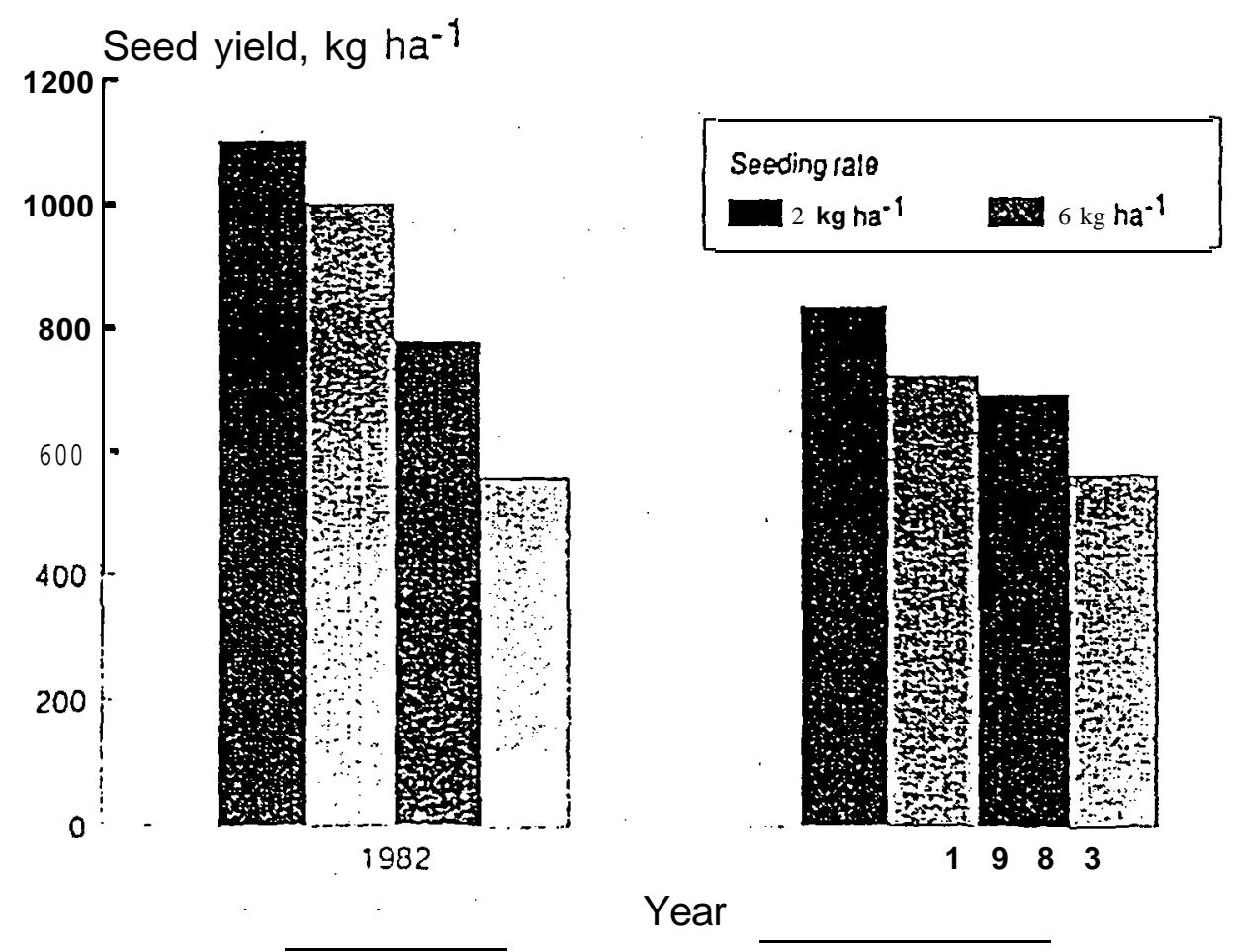




\section{4}

Fig. 3
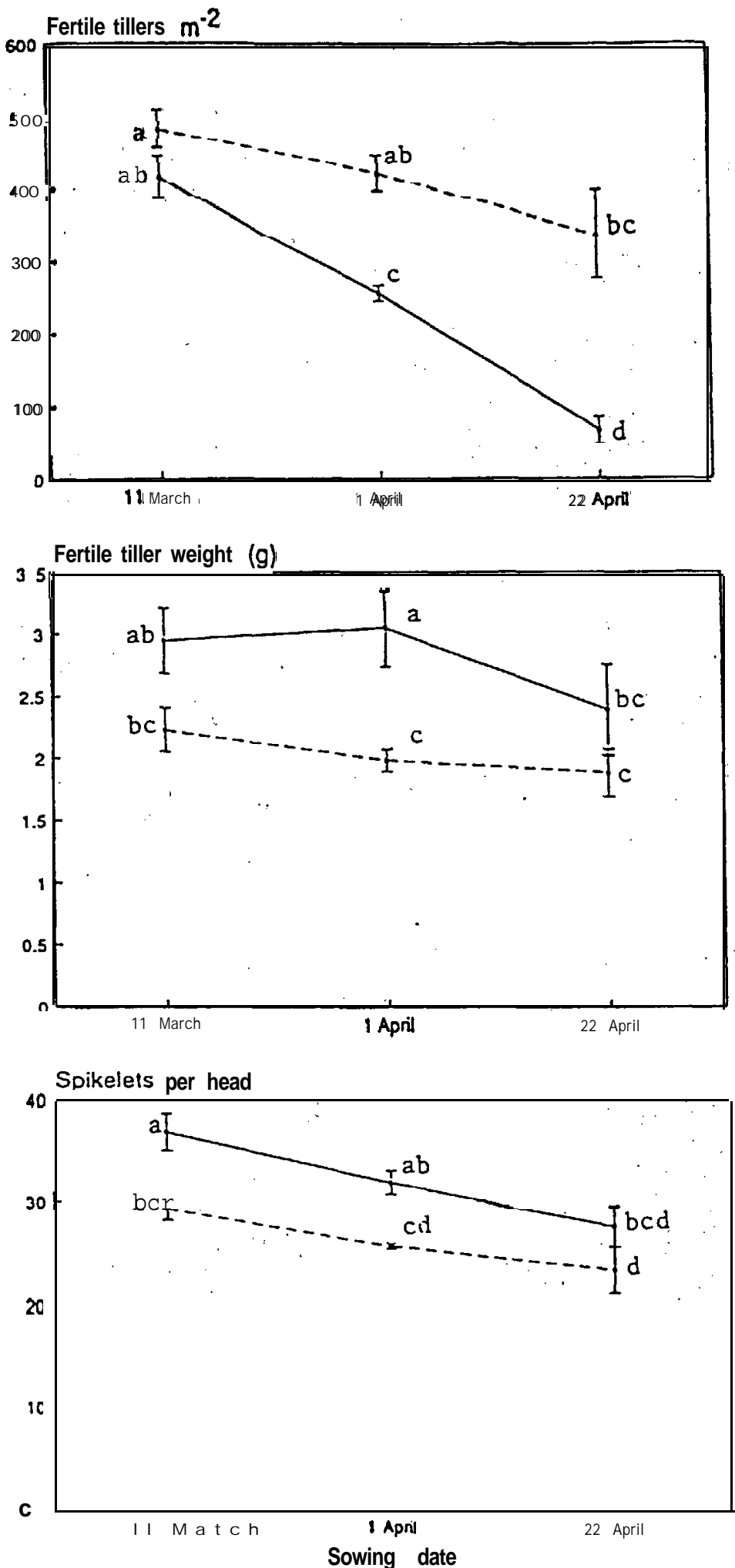

Mean numbers and dry weight of fertile tillers and spikelets per head in matua prairie grass sown on different dates in autumn 1986 at' $20 \mathrm{~kg}$ ha -1 $(--)$ and $5 \mathrm{~kg} \mathrm{ha}{ }^{=i}(-)$. (See Fig.l for statistical information). 
(Figure 1). Even though fertile tiller numbers were lower at $5 \mathrm{~kg}$ ha" the vigorous, heavy tillers produced more spikelets per tiller which increased seeds per unit area (Figure 5). A similar

situation occurred in Wana cocksfoot where a sowing rate of $2 \mathrm{~kg}$ ha" in early autumn (10 March) produced more seed for two consecutive seasons than a 6 $\mathrm{kg} \mathrm{ha}{ }^{-1}$ sowing rate (Figure 2 ).

While a low sowing rate is necessary for high seed yields in most cases, spring-sown Matua prairie grass seed crops yield better with high sowing rates (Table 2).

The actual drill width may be determined by the customary width used on the farm in general row crop work, rather than by a proven superiority of any given drill width to enhance seed yields. It is obviously an advantage to standardise this as far as possible over the whole range of farm crops for the ease of working row crop machinery. At the DSIR Grasslands' Aorangi farm in the Manawatu many of the implements have been

standardised to $60 \mathrm{~cm}$. This includes the Stanhay drill, rotary hoe, steerage hoe and tine cultivators. Thus inter-row cultivation for soil aeration end weed control is possible and grass populations are restricted to within the row.

British work found that, within limits, the precise drill width does not greatly influence seed yields, although species and cultivars do vary to some extent in their response. Brown, working in Canterbury, has found the sowing rate within the drill row should be reduced, rather than the drill width increased, as Matua seed yields generally decreased as row. width increased from 15 to $60 \mathrm{~cm}$.

With one to two year life crops (e.g., ryegrass and prairie grass, and fine turf grasses a row width of $15 \mathrm{~cm}$ with a low seeding rate generally produces highest yields. For long term crops (e.g., cocksfoot, tall fescue, and phalaris) row widths of $30-45 \mathrm{~cm}$ at low seeding rates gives highest yields. Wana sown at $15,30,45$ and $60 \mathrm{~cm}$ row widths gave the highest yield in $30 \mathrm{~cm}$ row widths. At Aorangi good yields from crops sown in $60 \mathrm{~cm}$ row widths can be obtained. However, row widths of above $60 \mathrm{~cm}$ would probably be wasteful in terms of optimum ground cover.

\section{CROP MANAGEMENT}

Grazing and closing: As a general rule a grass seed stand requires a period of rest in the autumn for growth and tiller formation to take place. Once the plant has made this growth, and the required number of tillers have been laid down, it normally does little harm to remove the excess top growth that has accumulated as long as the actual growing points are not damaged. Grazing is thought to be safe until stem elongation commences because young seedheads are below grazing height and there is little chance of their removal by grazing. Grazing often controls weeds without having to spray herbicides. 
Although good grass seed crop management and livestock farming can be combined easily, it is well known that large scale herbage seed production is being undertaken most successfully without livestock, e.g., in Denmark and Oregon.

Is it necessary, therefore, to winter graze grass seed crops? Brown found that mid-winter grazing and pre-closing grazing of Paroa, Nui and Moata were detrimental to seed production and it was better to grow specialist, ungrazed crops to obtain the highest possible seed yield. Although ungrazed crops tend to lodge, lodging problems could be solved with growth regulators and fungicides.

Roa tall fescue crops may be grazed any time between March and August without reducing seed yields significantly. Grazing can take place in many grass seed crops up until the closing. date without seed yields declining significantly. Perennial ryegrasses can be grazed up until mid-September and still yield over 1500 kg ha-' of seed. Cocksfoot seed crops should be closed earlier (July and August) and tall fescue at approximately the same time. With fine fescues any grazing or cutting after April decreases seed yields (Table 4). Autumn sown Matua can be grazed up until the end of September without adversely affecting seed yields.

Table 4. The effect of closing date on seed yield of fine fescue

$$
\text { Seed, Yield (kg ha-1) }
$$

Tasman Cook

Closing date

$\begin{array}{lll}\text { At harvest } & \mathbf{7 6 0} & \mathbf{4 5 0} \\ \text { April } & 930 & 490 \\ \text { May } & \mathbf{7 0 0} & \mathbf{4 2 0} \\ \text { July } & 380 & \mathbf{2 3 0}\end{array}$

\section{POST-HARVEST MANAGEMENT}

Post-harvest management is extremely important in order that the type of growth for maximum seed yield the following summer is encouraged. After harvest the excess summer foliage and stubble should be removed to open up the stand for light penetration and to encourage fresh, vigorous growth from 
ground level. With ageing stands, tiller density must be reduced and weeds controlled.

Burning: Oregon initiated burning in the 1940's to control blind seed disease in perennial ryegrass. Increased seed yields were observed and now burning has become an established management practice in grass seed production. Burning is an inexpensive method of removing the residue that, if left, would inhibit light interception and interfere with regrowth. Control of seed-crop pests and weeds is another established benefit.

Burning of post-harvest residue in perennial ryegrasses in Oregon removes most of the crop residue and organic matter accumulation, exposing considerable mineral-soil surface. Burning also causes the destruction of surviving tillers, resulting in a more open canopy. Subsequently there is earlier development of new tillers growing in more direct contact with the soil. These early tillers are shorter, more prostrate, and have more effective photosynthetic tissue for light-energy capture. As the more prostrate, short tillers result in less self-shading, light may be less limiting to growth. The exposed soil surface allows for a higher soil temperature during the day and cooler soil temperature at night, contributing to greater tillering and perhaps a more fully-induced state in more tillers. As a result, spring inflorescence emergence is greater and often more seeds per tiller result,

Burning must be done early before regrowth starts. Burning late, when regrowth has developed, can cause stand injury and is less effective in removing crop residue. Burning can be carried out effectively on browntop, fine fescue, tall fescue, cocksfoot, perennial ryegrass and phalaris.

In the Manawatu, burning fine fescues after harvest has not been any more effective than either close cutting or grazing (Table 5). In Oregon close cutting of fine fescues has also been found to be as effective as burning. Sheep do not like eating fine fescue crop residue and have to be pushed to eat it and clean the field up. Close cutting as soon as possible after harvest, windrowing the residue, and burning is the best method of post-harvest management in fine fescues,

Table 5. The effect of burning post-harvest residue of Cook fine fescue on seed yield (kg ha-') in the Manawatu.

Post-harvest treatment

\begin{tabular}{ccccc} 
Year & Burn & cut & Graze & Control \\
1 & 180 & 150 & 170 & 200 \\
2 & 500 & - & 510 & 450 \\
3 & 590 & 700 &. &. \\
\hline
\end{tabular}


Close stubble cutting: Where grass straw is baled for sale, close cutting the crop stubble is an effective method of post-harvest management, particularly in areas of high rainfall where good clean burning is not possible.

Grazing: Grazing the stubble can remove a lot of straw stalks and, if heavily stocked, open the stand up. However, grazing is probably not as effective as burning in reducing stand densities and would be best used in conjunction with atrazine spraying, inter-row cultivation or gapping.

Atrazine spraying: Atrazine (at 1.5 litres of product per hectare) can be sprayed on the crop once new seedlings from fallen seed appear between the rows. These seedlings are killed, so removing competition, and the mature, originally drilled plants tiller to contribute to next year's harvest. In this way plant densities are controlled so that tillers have adequate room for development without competition from a vast number of new tillers from fallen seed.

inter-row cultivation: Where growers have planted in wide rows and have the equipment, inter-row cultivation in early autumn is an effective method of postharvest management. The soil is then moister, allowing equipment to move freely, and emerging seedlings are destroyed. Inter-row cultivation also aerates the soil, which with stand age may become very compacted. Inter-row cultivation, because it occurs some time after harvest, is best used in conjunction with burning, grazing, and atrazine spraying.

Gapping: Gapping involves sections of drill-rows being removed by rotary cultivators or other implements driven across the drill-rows, In England this method has resulted in increased seed yields in stands of tall fescue and cocksfoot. For every $30 \mathrm{~cm}$ of row, $22 \mathrm{~cm}$ are removed, leaving $8 \mathrm{~cm}$ of row with plants to grow and develop. Gapping reduces the stand density and prevents overcrowding, allowing more space for tiller growth and development.

In browntop and fine fescue fields, where there is considerable turf buildup, some form of ripping or surface cultivation may be necessary to reduce this turf. The new browntops are not suited to the ploughing to which old New Zealand browntop stands were treated. A surface discing or heavy harrowing may be all that is necessary.

In summary, this paper has discussed the establishment and density of grass seed crops. Production is a full year cycle with on-going management required to produce consistently high seed yields. Seed stands should be established with as low a sowing rate as possible, and in subsequent years plant or tiller populations should be reduced to prevent tillers from becoming weak and low yielding from over-crowding. 